\title{
In vitro propagation from nodal segments of Lippia origanoides (chemotype A)
}

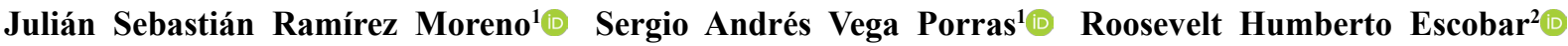 Elena E. Stashenko ${ }^{3}$ Jorge Luis Fuentes Lorenzo ${ }^{1}$ Luz Nayibe Garzón Gutiérrez ${ }^{1^{*}}$ (i)}

\author{
${ }^{1}$ Faculty of Science, School of Biology, Universidad Industrial de Santander (UIS), 680002, Bucaramanga, Santander, Colombia. E-mail \\ lngarzon@uis.edu.co. "Corresponding author. \\ ${ }^{2}$ The Alliance of Bioversity International and CIAT, Palmira, Valle del Cauca. Colombia. \\ ${ }^{3}$ Faculty of Science, School of Chemistry, Universidad Industrial de Santander (UIS), Bucaramanga, Santander, Colombia.
}

\begin{abstract}
This research described an efficient micropropagation protocol for Lippia origanoides (Verbenaceae). Sterile seeds were used to obtain germinated seedlings in Murashige and Skoog medium (MS) supplemented with sucrose and agar. The nodal segments obtained from seedlings were grown on MS medium supplemented with different concentrations of gibberellic acid (GA), benzylaminopurine (BAP) and 1-naphthalenacetic acid (NAA) with BAP. The callus induction, shoots length, shoots number and root length, were analyzed. The treatments showed high percentage of callus formation at 0.5 to $1.5 \mathrm{mg} \mathrm{L}^{-1}$ of BAP alone or in combination with NAA (0.1 mg $\left.L^{-1}\right)$. The highest value of shoot number per nodal segments was obtained at $1.5 \mathrm{mg} \mathrm{L} L^{-1}$ of BAP $(4.3 \pm 0.8)$. The obtained plantlets were better rooted in vitro in the absence of plant growth regulators (PGRs) and they showed acclimatization rate of $90 \%$. We reported a protocol for in vitro propagation and acclimatization of L. origanoides for A chemotypes from Colombia.
\end{abstract}

Key words: micropropagation, shoot multiplication, nodal culture.

Propagação in vitro de segmentos nodais de Lippia origanoides (quimiotipo A)

RESUMO: Esta pesquisa descreve um protocolo de micropropagação eficiente para Lippia origanoides (Verbenaceae). Sementes estéreis foram utilizadas para a obtenção de mudas germinadas em meio Murashige e Skoog (MS) suplementado com sacarose e ágar. Os segmentos nodais obtidos das mudas foram cultivados em meio MS, suplementado com diferentes concentrações de ácido giberélico (GA), benzilaminopurina (BAP) e ácido 1-naftalenacético (ANA) com BAP. Foram analisados a indução de calo, comprimento de brotação, número de brotação e comprimento de raiz. Os tratamentos mostraram alta porcentagem de formação de calo com 0,5 a 1,5 mg L-1 de BAP sozinho ou em combinação com ANA (0,1 mg L-1). O maior valor de número de brotações por segmento nodal foi obtido com 1,5 mg L-1 de BAP (4,3 $\pm 0,8)$. As mudas obtidas apresentaram melhor enraizamento in vitro na ausência de reguladores de crescimento vegetal (PGRs) e demonstraram taxa de aclimatação de $90 \%$. Contudo, relata-se um protocolo para propagação in vitro e aclimatação de L. origanoides para quimiotipos A da Colombia.

Palavras-chave: micropropagação, multiplicação de ramos, cultura nodal.

The genus Lippia belongs to the Verbenaceae family and comprises about 200 species, including grasses, shrubs, and small trees. It mainly occurs in South and Central America and tropical Africa (ATKINS, 2004). Several studies have revealed that Lippia spp. contain bioactive compounds with a wide range of biological activities and potential sources for treating different diseases (MASUNDA et al. 2020; LEYVA-JIMÉNEZ et al. 2019; PASCUAL et al. 2001).

Lippia origanoides is an aromatic shrub native to Central America and northern region of South America (VICUÑA et al. 2010). It is characterized by its antibacterial, antifungal, antiviral, antiparasitic, antioxidant, antigenotoxic, and anticancer biological activities (CELIS et al. 2007; MENESES et al. 2009; OLIVEIRA et al. 2007; QUINTERO-RUIZ et al. 2017; RAMAN et al. 2017; SANTOS et al. 2004; STASHENKO et al. 2014), attributed to components of its essential oil and extracts. It has also been shown that $L$. origanoides has at least five chemotypes according to its essential oil major component (A, B, $\mathrm{C}, \mathrm{D}$ and $\mathrm{E}$ ) used in the cosmetics and pharmaceutical industries (RIBEIRO et al. 2014; SILVA et al. 2009; STASHENKO et al. 2010).

This plant also contains flavonoids such as pinocembrin (LEITÃO et al. 2017; 
STASHENKO et al. 2013), a. A natural compound with pharmacological properties, including ischemic stroke, neurodegenerative diseases, and atherosclerosis (LAN et al. 2017). It is present only in the extract of Lippia origanoides chemotype A, which is exclusive of Colombia (STASHENKO et al. 2013). In addition, chemotype A also has the highest profitability in the extraction process of its products (ARIAS et al. 2020).

Attempts to propagate L. origanoides by conventional methods as "sticks and cuttings" and seeds have shown a lower rooting capacity and a delayed development (HERRERA-MORENO et al. 2013; SILVA et al. 2015). Therefore, it is essential to use alternative techniques to produce large amounts of biomass in a short time that allows supplying the industry demand. An option is plant propagation by tissue culture, a useful tool to optimize plant production of superior qualities, free from microorganisms and with high multiplication rates (LONE et al. 2020). However, a major limitation in large scale application of this technology is high mortality experienced by micropropagated plants during or following laboratory to land transfer (CHANDRA et al. 2010).

Although, the in vitro micropropagation technique has been efficient and described for some species of the genus Lippia (CASTELLANOSHERNÁNDEZ et al., 2013; GUPTA et al. 2001; JOSÉ et al. 2019; JULIANI et al. 1999; PEIXOTO et al. 2006; RESENDE et al. 2015), currently, there is only a single report on the effects of different PGRs (benzylaminopurine, indole acetic acid and kinetin) on in vitro development of L. origanoides (CASTILHO et al. 2019). It is important to point out that this approach does not describe a useful methodology for ex vitro acclimatization. Considering that plant's response to in vitro culture varies between samples collected from different geographic locations (HAQUE \& GOSH 2018; MANVI \& PARASHARAMI 2019), this work established a protocol for in vitro propagation and ex vitro acclimatization of $L$. origanoides for A chemotype exclusive from Colombia.

The inflorescences of $L$. origanoides plants (A chemotype), were collected from experimental gardens at "Centro Nacional de Investigaciones para la Agro industrialización de Especies Vegetales Aromáticas Medicinales Tropicales (CENIVAM)", located at Universidad Industrial de Santander, (Bucaramanga, Colombia). These inflorescences were dried in the oven for $24 \mathrm{~h}$ at $34{ }^{\circ} \mathrm{C}$ until their use.

For seed germination, we used the MS medium (Murashige and Skoog, 1962) prepared at $1 / 2$ strength and supplemented with $1.5 \% \mathrm{w} / \mathrm{v}$ sucrose and $0.7 \% \mathrm{w} / \mathrm{v}$ agar (Caisson) at $\mathrm{pH} 5.8$, as it was indicated by CASTELLANOS-HERNÁNDEZ et al., (2013). The seeds were immersed in $70 \%$ ethanol ( $1 \mathrm{~min}$ ), followed by immersion in $4 \%$ sodium hypochlorite $(12 \mathrm{~min})$ and then were washed three times with sterile and distilled water. The seeds were germinated in $60 \times 70 \mathrm{~mm}$ flask containing $20 \mathrm{~mL}$ of MS medium. The containers were maintained at $25 \pm$ $2{ }^{\circ} \mathrm{C}$ with a $16 \mathrm{~h}$ photoperiod, provided by white and cold fluorescent tubes with an intensity of $50 \mu \mathrm{mol}$ $\mathrm{m}^{-1} \mathrm{~s}^{-1}$ (Sylvania Toledo Glass Tube 9w TB G13). For determination of germination and contamination rates, five replications of 10 seeds were used and germination was scored by visual observation of radicle emergence posterior to 20 days. After six weeks, the nodal segments of the seedlings (with average length of $4.1 \mathrm{~cm}$ ) were used as a source of explants for the multiplication stage.

The culture media (Table 1) was the MS medium with $3 \% \mathrm{w} / \mathrm{v}$ sucrose supplemented with $\mathrm{NAA}$ at $0.1 \mathrm{mg} \mathrm{L}^{-1}$ and different concentrations of GA and BAP, as follows: $\mathrm{GA}\left(0.5,1,1.5 \mathrm{mg} \mathrm{L}^{-1}\right)$, BAP $\left(0.5,1,1.5 \mathrm{mg} \mathrm{L}^{-1}\right)$. Nodal segments (approximately $1 \mathrm{~cm}$ ) were obtained from 6 weeks old in vitro seedlings and were inoculated into different media. Each treatment was composed by one explant per flask with four replicates and three repetitions. After the sixth week, we estimated the callus percentage, the number of shoots, and the shoot's length and roots per explants.

Plantlets with well-developed roots (root length greater than $3 \mathrm{~cm}$ ) were removed from the culture medium and washed with distilled and sterilized water to remove the adhering medium. They were transplanted in sealable plastic bags with different substrates such as river sand, black peat and vermicompost, and all were previously sterilized (Figure 1). Fifteen plantlets were transplanted for each substrate. The bags were transferred to a greenhouse and were opened gradually until ten days and were irrigated with tap water every 3 days. After 6 weeks, plantlets were transferred to field conditions.

All experiments were performed under a completely randomized design. The collected data were normalized $\left(\log _{10}\right)$, and a factor variance analysis was performed at a significance level of $\mathrm{P}$ $<0.05$, followed by a Tukey multiple range test. The RStudio 1.0.143 program for Windows was used.

In vitro germination of $L$. origanoides seeds collected from the field was performed to obtain axenic seedlings as sources of explants for plant propagation. After ten days the average germination rate of seedlings explants was $60 \%$. Contamination was observed in less than $20 \%$ 
Table 1 - Treatments used for germination, multiplication and rooting of nodal segments of chemotype A L. origanoides explants.

\begin{tabular}{|c|c|c|c|c|c|c|}
\hline \multicolumn{3}{|c|}{------------Concentration (mg/L)----------- } & \multirow[t]{2}{*}{ Callus $(\%)$} & \multirow[t]{2}{*}{ No of explant shoots } & \multirow[t]{2}{*}{ Shoot length $(\mathrm{cm})$} & \multirow[t]{2}{*}{ Root length $(\mathrm{cm})$} \\
\hline GA & BAP & NAA & & & & \\
\hline 0.5 & 0 & 0 & 0 & $1.7 \pm 0.2 \mathrm{bc}$ & $5.8 \pm 1.3 \mathrm{a}$ & $8.6 \pm 3.1 \mathrm{a}$ \\
\hline 1 & 0 & 0 & 0 & $1.2 \pm 0.3 \mathrm{c}$ & $3.2 \pm 1.0 \mathrm{bc}$ & $2.0 \pm 0.3 b c$ \\
\hline 1.5 & 0 & 0 & 0 & $1.4 \pm 0.4 b c$ & $4.4 \pm 0.7 \mathrm{ab}$ & $3.5 \pm 1.7 \mathrm{ab}$ \\
\hline 0 & 0.5 & 0 & $89 \%$ & $2.3 \pm 1.3 \mathrm{abc}$ & $2.9 \pm 0.1 \mathrm{bcd}$ & $1.9 \pm 0.7 b c$ \\
\hline 0 & 1 & 0 & $92 \%$ & $3.4 \pm 1.3 \mathrm{ab}$ & $2.3 \pm 0.4$ cde & $2.3 \pm 1.0 \mathrm{bc}$ \\
\hline 0 & 1.5 & 0 & $100 \%$ & $4.3 \pm 0.8 \mathrm{a}$ & $3.1 \pm 1.1 \mathrm{bc}$ & $4.1 \pm 1.4 \mathrm{ab}$ \\
\hline 0 & 0.5 & 0.1 & $100 \%$ & $1.5 \pm 0.4 \mathrm{bc}$ & $1.8 \pm 0.4 \mathrm{de}$ & $0.9 \pm 0.4 \mathrm{~cd}$ \\
\hline 0 & 1 & 0.1 & $100 \%$ & $1.9 \pm 1.0 \mathrm{abc}$ & $1.6 \pm 0.2 \mathrm{e}$ & $1.8 \pm 0.7 \mathrm{bc}$ \\
\hline 0 & 1.5 & 0.1 & $100 \%$ & $2.2 \pm 0.9 \mathrm{abc}$ & $1.4 \pm 0.3 \mathrm{e}$ & $0.4 \pm 0.1 \mathrm{~d}$ \\
\hline 0 & 0 & 0 & 0 & $1.7 \pm 0.5 b c$ & $4.7 \pm 0.7 \mathrm{ab}$ & $6.5 \pm 4.6 \mathrm{ab}$ \\
\hline
\end{tabular}

The letters represent homogeneous groups; within each column, different letters indicate a significant difference at $\mathrm{P}<0.05$ using ANOVA and the Tukey HSD test.

Values are expressed as the mean \pm standard deviation of the mean.

of seeds. Similar results were obtained with $L$. graveolens (CASTELLANOS-HERNÁNDEZ et al., 2013) since we used the same medium.

Nodal explants showed a high percentage of callus formation in treatments with BAP alone or in combination with NAA (Table 1). Callus initiation was observed from the explants within 20-30 days of inoculation. Maximum callus induction $(100 \%)$ was detected from nodal explants cultured on MS medium with $0.1 \mathrm{mg} \mathrm{L}^{-1} \mathrm{NAA}$ and any concentration of BAP. In other Lippia species the addition of BAP also favored callusing at the lower end of the nodal stem explants (CASTELLANOS-HERNÁNDEZ et al. 2013, GUPTA et al. 2001; JOSÉ et al. 2019; MARINHO et al. 2011; RESENDE et al. 2015), including the study of L. origanoides from Brazil (CASTILHO et al. 2019).
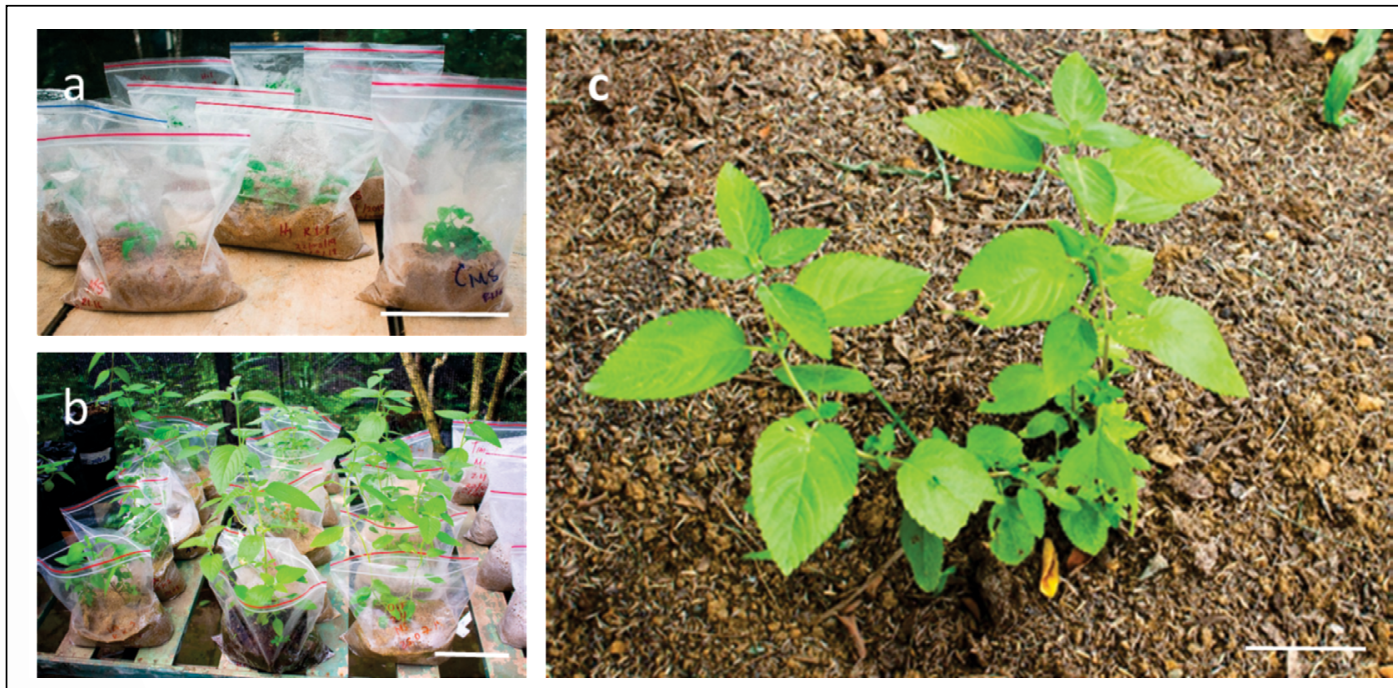

Figure 1 - L. origanoides plantlets (phellandrene chemotype) in the adaptation phase. a. Plantlets recently transplanted in bags; b. Plants adapted for 4 weeks; c. Field transplanted plants (6 weeks). Scale bar $(10 \mathrm{~cm})$. 
Culture of nodal explants on media supplemented with $1.5 \mathrm{mg} \mathrm{L}^{-1}$ of BAP resulted in significant differences in the number of shoots compared to control medium (Table 1). The highest values for shoot number per explants was obtained in the medium supplemented with BAP despite the fact that they did not have significant differences with other treatments. The addition of $0.1 \mathrm{mg} \mathrm{L}^{-1} \mathrm{NAA}$ in combination with BAP showed no statistically significant difference from treatments with BAP alone in terms of number of shoots (Figure 2; Table 1).

The beneficial effects of cytokinin during in vitro plant propagation, as report here, are in agreement with the results obtained in other species of Lippia, such as L. junneliana (JULIANI et al. 1999), L. alba (GUPTA et al. 2001), L. javanica (ARA et al. 2010), L. nodiflora (PRIYA \& RAVINDHRAN, 2011) and L. filifolia (PEIXOTO et al. 2006), but in this case, the combination with NAA results in the highest multiple shoot response.

Nevertheless, in vitro propagation of $L$. origanoides from Brazil, the best result showed shoot regeneration was with a medium free of PGRs(CASTILHO et al. 2019), demonstrating that plant's response to in vitro culture varies between different geographic locations, regardless of being the same species.

Healthy elongated shoots were obtained on MS medium with 0.5 and $1.5 \mathrm{mg} \mathrm{L}^{-1}$ of GA and medium free of PGRs $(4.7 \pm 0.7)$. The effect of GA has not been reported in other Lippia species. This result is consistent with similar findings in L. dulcis (URREA et al. 2010) and L. junelliana (JULIANI et al. 1999), where the mean shoot length was higher in a medium free of PGRs. However, it is the opposite of CASTILHO et al.( 2019) reported since the medium without PGRs did not affect the shoot length. Once more, indicating the need to establish propagation protocols for plants of the same species with differences in their localities.

Conversely using $1 \mathrm{mg} \mathrm{L}^{-1}$ of BAP or BAP in combination with NAA showed a lower capacity of the development of the length of the shoot. In contrast, the use of NAA and BAP + NAA in in vitro cultures explants from L. filifolia (PEIXOTO et al. 2006) and

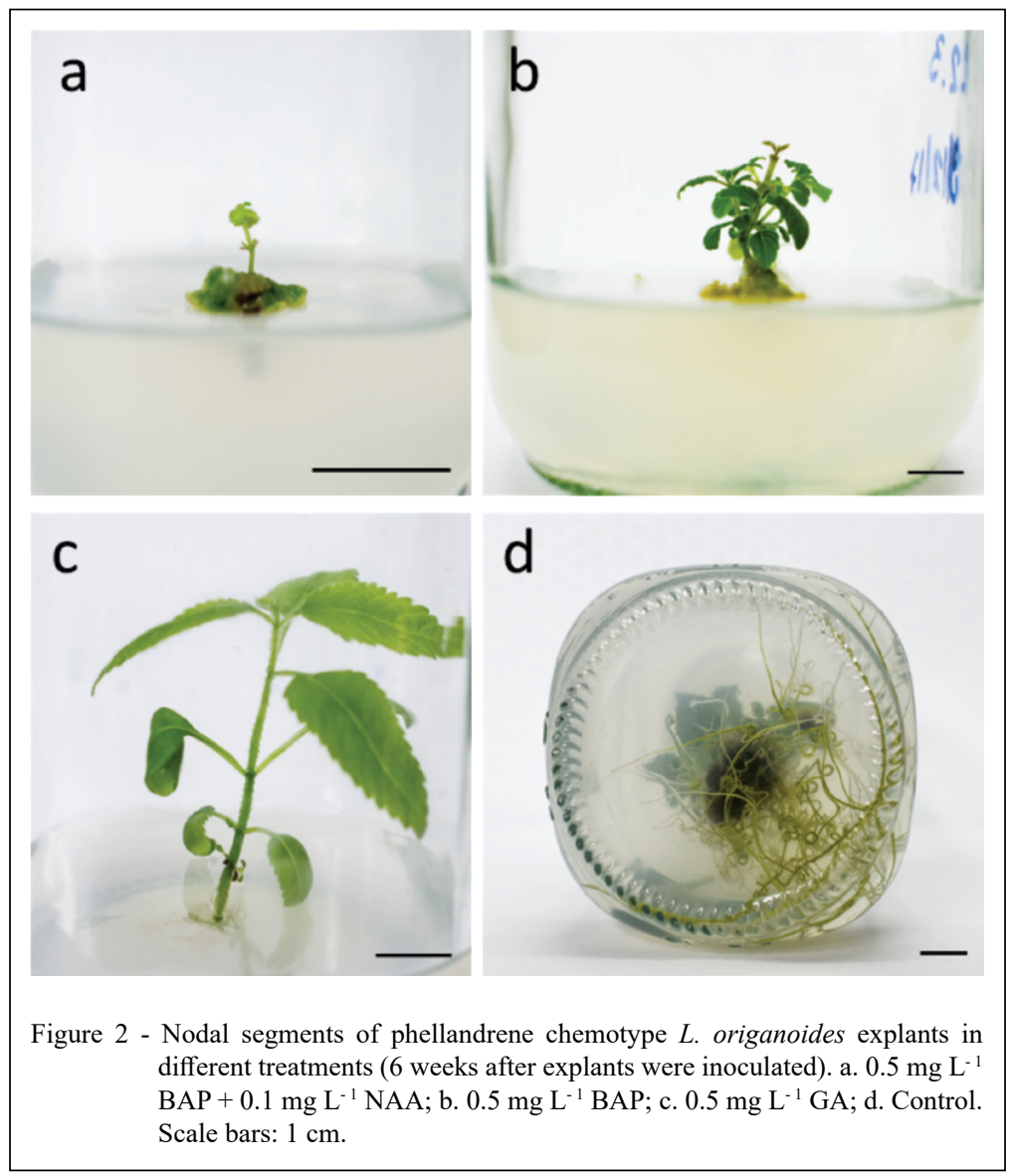

Ciência Rural, v.52, n.7, 2022. 
L. rotundifolia (RESENDE et al. 2015); respectively, improved shoot length. Since the incorporation of BAP into the culture medium, it is used primarily to induce shoot proliferation (BHOJWANI et al. 2013); therefore, it is expected that it will not have a positive effect on stem elongation by itself.

The highest value for shoot rooting was observed at $0.5 \mathrm{mg} \mathrm{L}^{-1}$ of GA $(8.6 \pm 3.1)$ and control treatment $(6.5 \pm 4.6)$. Increasing the GA concentration reduced the length of roots. Although, nodal explants have a positive response on MS medium with $0.5 \mathrm{mg} \mathrm{L}^{-1}$ of GA, our results suggested that it is unnecessary PGRs to obtain elongated and rooting shoots of $L$. origanoides since there was not significant differences with control. This was also reported for L. dulcis (URREA et al. 2010), where MS medium was the best treatment.

After hardening in sand and peat substrates for four weeks, regenerated L. origanoides plantlet survival was over $90 \%$ but only $60 \%$ in vermicompost substrate (Figure 1). Despite the high mortality often observed upon transfer plants to ex vitro conditions (CHANDRA et al. 2010), plants obtained in vitro from $L$. origanoides do not present this difficulty, since it was only necessary to gradually decrease the humidity to get healthy plants. All the plants survival the transfer to the field.

The method described in the present study provided an efficient reproducible protocol for in vitro micropropagation of $L$. origanoides (A). This technique is an alternative to traditional propagation methods for this promising aromatic species. The application of the protocol will facilitate research into the any major volatile component that proved to have industrial value and it could stimulate their development on a commercial scale.

\section{BIOETHICS AND BIOSSECURITY COMMITTEE APPROVAL}

The projects were also approved by the Ethical Committee (Record $\mathrm{N}^{\circ}$. 22) from UIS.

\section{ACKNOWLEDGEMENTS}

The authors thank funding from the Ministry of Science, Technology and Innovation, the Ministry of Education, the Ministry of Industry, Commerce and Tourism, and ICETEX, Programme Ecosistema Cientifico-Colombia Cientifica, from the Francisco José de Caldas Fund (Grand RC-FP44842-212-2018).

\section{DECLARATION OF CONFLICT OF INTEREST}

The authors declare no conflict of interest. The founding sponsors had no role in the design of the study; in the collection, analyses, or interpretation of data; in the writing of the manuscript, and in the decision to publish the results.

\section{AUTHORS' CONTRIBUTIONS}

The authors contributed equally to the manuscript.

\section{REFERENCES}

ARA, N. et al. A study of plant growth hormones on in vitro clonal propagation of fever tea (Lippia javanica): A medicinal shrub. American-Eurasian Journal of Sustainable Agriculture, v.4, p.274-279, 2010. Available from: <https:/www.researchgate.net/ publication/230601374_A_Study_of_Plant_Growth_Hormones on_in_Vitro_Clonal_Propagation_of_Fever_Tea_Lippia_ Javanica_a_Medicinal_Shrub>.Accessed: Mar. 06, 2021.

ATKINS, S. Verbenaceae. In: KUBITZKI, K; KADEREIT, J.W.The families and genera of vascular plants. Germany: Springer-Verlag, 2004. p.449-468.

BHOJWANI, S.S. et al. Plant tissue culture: An introductory text. Agra: Springer, 2013. 309p.

CASTELLANOS-HERNÁNDEZ, O. A. et al. In vitro clonal propagation and regeneration of the commercially important plant Mexican oregano (Lippia graveolens). In Vitro Cellular and Developmental Biology-Plant, v.49, p.620-625, 2010. Available from: <https://link.springer.com/article/10.1007/ s11627-013-9538-4>. Accessed: Mar. 06, 2021. doi: 10.1016/j. indcrop.2019.01.006.

CASTILHO, C. V. V. et al. In vitro propagation of a carvacrolproducing type of Lippia origanoides Kunth: A promising oregano-like herb. Industrial Crops and Products, v.130, p.491-498, 2019. Available from: <https://doi.org/10.1016/j. indcrop.2019.01.006>. Accessed: Mar. 06, 2021. doi: 10.1016/j. indcrop.2019.01.006.

CHANDRA, S. et al. Acclimatization of tissue cultured plantlets: From laboratory to land. Biotechnology Letters, v. 32, p. 1199 1205. 2010. Available from: <http://link.springer.com/10.1007/ s10529-010-0290-0>. Accessed: Mar. 06, 2021. doi: 10.1007/ s10529-010-0290-0.

GUPTA, S. K. et al. In vitro micropropagation of Lippia alba. Current Science, v.81, p.206-210. 2001. Available from: $<$ https:// link.springer.com/article/10.1079/IVP2006814>. Accessed: Mar. 06, 2021. doi: 10.1079/IVP2006814.

HAQUE, S. M.; GHOSH, B. An improved micropropagation protocol for the recalcitrant plant Capsicum-a study with ten cultivars of Capsicum spp. (C. annuum, C. chinense, and $C$. frutescens) collected from diverse geographical regions of India and Mexico. Journal of Horticultural Science and Biotechnology, v.93, p.91-99. 2018. Available from: $<$ https://doi. org/10.1080/14620316.2017.1345331>. Accessed: Mar. 06, 2021. doi: $10.1080 / 14620316.2017 .1345331$.

HERRERA-MORENO, A. M. et al. Establishment of propagation methods for growing promising aromatic plant species of the Lippia (Verbenaceae) and Tagetes (Asteraceae) genera in Colombia. Agronomía Colombiana, v.31, p.27-37. 2013. Available from: <https://revistas.unal.edu.co/index.php/agrocol/ article/view/29494>. Accessed: Mar. 09, 202.

Ciência Rural, v.52, n.7, 2022. 
JOSÉ, D. P. et al. Micropropagation and ploidy stability of Lippia lacunosa Mart. \& Schauer: an endangered brazilian medicinal plant. Journal of Neotropical Agriculture, v.6, p.1-7. 2019. Available from: <https://periodicosonline.uems.br/index.php/ agrineo/article/view/3203>. Accessed: Mar. 09, 2021. doi: 10.32404/rean.v6i1.3203.

JULIANI, H. R. et al. Micropropagation of Lippia junelliana (Mold.) Tronc. Plant Cell, Tissue and Organ Culture, v.59, p.175-179. 1999. Available from: <https://link.springer.com/arti cle/10.1023/A:1006396531647>. Accessed: Mar. 09, 2021. doi: 10.1023/A:1006396531647.

LEYVA-JIMÉNEZ, F. J. et al. Functional ingredients based on nutritional phenolics. a case study against inflammation: Lippia genus. Nutrients, v.11, p.2-24. 2019. Available from: <https:// www.mdpi.com/2072-6643/11/7/1646>. Accessed: Mar. 09, 2021. doi: $10.3390 /$ nu11071646.

LONE, S. M. et al. Plant propagation through tissue culture -a biotechnological intervention Int.J.Curr.Microbiol.App.Sci, v.9, p.2176-2190. 2020. Available from: <https:/www.ijcmas. com/abstractview.php?ID=18227\&vol=9-7-2020\&SNo=254>. Accessed: Mar. 09, 2021. doi: 10.20546/ijcmas.2020.907.254.

MANVI, S.; PARASHARAMI, V. Garcinia indica choisy: screening of location for donor female mother plants for micropropagation with effective protocol for establishment of sterile and healthy cultures. Acta Scientific Agriculture, 2019. v.3, p.39-48. 2019. Available from: <https://actascientific.com/ ASAG/pdf/ASAG-03-0514.pdf>. Accessed: Mar. 09, 2021. doi: 10.31080/ASAG.2019.03.0514.

MARINHO, M. J. et al. Establishment of protocol for Lippia gracilis Schauer micropropagation. Revista Brasileira de Plantas Medicinais, v.13, p.246-252. 2011. Available from: $<$ http://dx.doi. org/10.1590/S1516-05722011000200019>. Accessed: Mar. 09, 2021. doi: 10.1590/S1516-05722011000200019.

MASUNDA, A. T. et al. Traditional uses, physical properties, phytochemistry and bioactivity of Lippia multiflora Moldenke (Verbenaceae): A Mini-review. Discovery Phytomedicine, v.7, p.19-26. 2020. Available from: <https://www.researchgate.net/ publication/339460113_Traditional_uses_Physical_properties Phytochemistry_and_Bioactivity_of_Lippia_multiflora_ Moldenke_Verbenaceae A Mini-review>. Accessed: Mar. 09, 2021. doi: 10.15562/phytomedicine.2020.114.

PASCUAL, M. E. et al. Lippia: Traditional uses, chemistry and pharmacology: A review. Journal of ethnopharmacology, v.76, p.201-214. 2001. Available from: <http://www.ncbi.nlm.nih. gov/pubmed/11448540>. Accessed: Mar. 09, 2021. doi: 10.1016/ s0378-8741(01)00234-3.
PEIXOTO, P. H. P. et al. In vitro propagation of endangered Lippia filifolia Mart. and Schauer ex Schauer. In Vitro Cellular \& Developmental Biology - Plant, v. 42, p. 558-561. 2006. Available from: <https://agris.fao.org/agris-search/search. do? recordID $=$ US201500203677>. Accessed: Mar. 09, 2021. doi: 10.1079/IVP2006814.

PRIYA, E.; RAVINDHRAN, R. Micropropagation of Lippia nodiflora using shoot tip and nodal explants under in vitro conditions. International Journal, v.3, p.43-47. 2011. Available from: <https://www.semanticscholar.org/paper/ MICROPROPAGATION-OF-LIPPIA-NODIFLORA-USINGSHOOT-IN-Priya-Ravindhran/06e338e9ebcd7da24aefe67bb9fa88 d9865b4abd>. Accessed: Mar. 09, 2021.

RESENDE, C. F. et al. In vitro propagation and acclimatization of Lippia rotundifolia, an endemic species of Brazilian Campos Rupestres. Revista Ciencia Agronomica, v.46, p.582-589. 2015. Available from: $<$ https://www.scielo.br/scielo.php?script $=$ sci_artte xt\&pid=S1806-66902015000300582 >. Accessed: Mar. 09, 2021. doi: 10.5935/1806-6690.20150041.

RIBEIRO, A. F. et al. Circadian and seasonal study of the cinnamate chemotype from Lippia origanoides Kunth. Biochemical Systematics and Ecology, v.55, p.249-259. 2014. Available from: $<$ http://dx.doi.org/10.1016/j.bse.2014.03.014>. Accessed: Mar. 09, 2021. doi: 10.1016/j.bse.2014.03.014.

SILVA, G. C. et al. Propagação vegetativa e crescimento inicial de Lippia origanoides (Alecrim-de-tabuleiro). Horticultura Brasileira, v.33, p.236-240. 2015. Available from: <http://www. scielo.br/scielo.php?script $=$ sci_arttext\&pid $=$ S0102-05362>. Accessed: Mar. 09, 2021. doi: 10.1590/S0102053620150000200016.

SILVA, N. A. et al. Essential Oil composition and antioxidant capacity of Lippia schomburgkiana. Natural Product Communications, v.7, p.1281-1286. 2009. Available from: $<$ https://pubmed.ncbi.nlm.nih.gov/19831045/>. Accessed: Mar. 09, 2021. doi: 10.1177/1934578x0900400925.

URREA, A.; CASTRILlÓN, P.; MONSALVE, Z. Propagación in vitro y desdiferenciación tisular en Lippia dulcis. Actualidadesds Biológicas, v.31, p.21-29. 2010. Available from: <https:// revistas.udea.edu.co/index.php/actbio/article/view/4726>. Accessed: Mar. 09, 2021.

VICUÑA, G. C. et al. Chemical composition of the Lippia origanoides essential oils and their antigenotoxicity against bleomycin-induced DNA damage. Fitoterapia, v.81, p.343349. 2010. Available from: <https://pubmed.ncbi.nlm.nih. gov/19874875/>. Accessed: Mar. 09, 2021. doi: 10.1016/j. fitote.2009.10.008. 